\title{
UNDERSTANDING VISITOR PREFERENCES IN OLD OYO NATIONAL PARK, NIGERIA
}

\author{
${ }^{1}$ Arowosafe, F. C., ${ }^{2 *}$ Kuuder, C. J. W., ${ }^{1}$ Bokyaa, D. T. \\ ${ }^{1}$ Department of Ecotourism and Wildlife Management, Federal University of Technology,Akure, Ondo State, Nigeria, \\ ${ }^{2}$ Department of Ecotourism and Hospitality Management, University for Development Studies, Nyankpala Campus, Tamale, Ghana.
}

*Corresponding Author's Email: kwuleka@uds.edu.gh

\begin{abstract}
This study sheds light on visitors' preferences in Old Oyo National Park (Nigeria) and how these preferences contributed to their travel experience. A total of 120 visitors were reached via convenience sampling employing questionnaire administration. Their preferences were measured with the aid of a Likert scale and choice cards. Data collected were analyzed using descriptive statistics and conditional logit specification for inferential statistics. The results revealed that entrance fees, availability of affordable chalet accommodation, wildlife viewing opportunities and visits to the relics of the old city wall of Oyo Ile were the significant site predictors of choosing the park as a preferred tourist destination. Easy access within the park and good staff courtesies also had high means of 4.21 and 4.16 respectively, demonstrating site features and hospitality services rendered lends credence to visitor decision on destination choice. The park management needs to continually research on attractions and make efforts at improving such to entice repeat visits.
\end{abstract}

\section{Keywords: Old Oyo National Park, Hospitality Services, Visitor Preferences, Site Features, Experiences}

\section{Introduction}

The economic merits of tourism are numerous and often provide an attractive basis for economic development through improving local communities' economic situations by creating new jobs, new investments and increasing government earnings through foreign exchange (Chandler \& Costello, 2002). Worldwide, growth in the tourism industry was recorded as one of the most significant achievements over the last 50 years with an annual rate of $9 \%$, generating $10 \%$ of the global gross domestic product [GDP] (Honey \& Krantz, 2007).

In recent years, governments have begun promoting tourism in response to the trend of globalization and the needs of domestic development while intending to create economic benefits for the society by developing tourism (Mihajlović \& Krželj-Čolović, 2014). Tourists have varied impressions of
The Central Bank of Nigeria discovered that there has been a dynamic improvement in the Nigerian tourism industry resulting in an aggregate number of 828,906 tourists who visited the country in 2007 (Ogunberu, 2011). As at December 2016, it came to light that a total of 1,889,000 tourists visited Nigeria (Census and Economic Information Centre [CEIC] Global Database, 2019) and this has made the tourism industry a power to reckon with in the country among other sectors, particularly taking a cue from the financial inflow perspective.

destinations depending on the availability of facilities and opportunities offered and the sort of experiences gained (Shiang, Gin \& Shih, 2011). In this light, tourists' amusement and satisfaction to a great extent depend on the accessibility and exciting 
nature of tourism related services at a destination (Kariru \& Aloo, 2014).

The physical condition of a hospitality outlet assumes an essential part in consumer fulfillment and brings about enthusiasm and the possibility of a return to same destination thereby creating a platform for budgetary success (Magnini \& Parker, 2009). A few studies have demonstrated that physical and or environmental conditions of a destination assumes a part in building up clients' preutilization mindset before the genuine service is actually rendered (Githiri, 2016). This seeks to suggest that the environment influences quality desires and impressions formed with respect to utilization of tourism products and services (Tuzukan \& Albayrac, 2016).

The International Finance Corporation [IFC] (2004) compiled a report on protected area accommodation related developments including nature-based tourists' preferences, which revealed the fact that tourists expect value for money and desire more of traditional accommodation that is eco-friendly. The same report emphasized accommodation should be located near places where viewing wildlife movement is greatly enhanced. Other 'eye-catching' merits espoused included scenic qualities and unique indigenous architectural designs. The most important aspect for tourists in nature-based facilities is the natural setting, which is, the scenic beauty and ambiance where accommodation facilities are located are considered very important. (Dolnicar et al., 2008).

Offering tourism opportunities while minimizing environmental impacts remains an ongoing task for park authorities that should be consistently based on a systematic evaluation of tourists' preferences and behaviour (Juutinen et al., 2011). Preferences refer to the tradeoffs between social, economic, and

\section{Methodology \\ Profile of the Park}

The Old Oyo National Park is located across northern Oyo State and Southern Kwara State, Nigeria. The park occupies $2,512 \mathrm{~km}^{2}$ of land in Northern Oyo ecological values of goods and services provided for by protected areas (Prato \& Fagre, 2005). There is therefore need to understand tourists' preferences for national park characteristics in order to develop services that respond to the dual goals of conservation and tourism development (Hearne \& Salinas, 2002).

A recent study has shown that the concept of sustainable tourism is viewed differently by different attitudinal groups (Hardy \& Pearson, 2016), thus, tourists' preferences be given an in-depth study and more attention should be paid at the managerial level for the purpose of rendering memorable services which will woo more guests through word of mouth and repeat visits. It is a truism that knowledge and understanding of tourists' preferences and expectations can lead to better tourism planning ( $\mathrm{Oh}$ et al., 2010) as it often provides a detailed insight of the real demand situation for easy comprehension by planners (Kajala et al., 2007). This therefore brings to the fore the essence of this article, which is, an attempt at exploring visitor preferences in terms of hospitality services offered therein in addition to ascertaining the variety of attractions and features Old Oyo National Park has on offer to its clientele who access the facility. The research gap that this study therefore seeks to fill is seen in the fact that many tourism facilities with their staff often pay more attention to the service provision end of the coin and relegate to the background what the customers really expect. In this regard, a gap frequently exists culminating in the service providers' inability to use his/her ingenuity to tap into what makes customers either happy or dissatisfied in a destination, hence their failure to capitalize on the opportunity to make amends for a better experience of the visitor in the destination area

State, south west of Nigeria specifically at latitude $8^{0}$ $15^{\prime}$ and $9^{0} 00^{\prime} \mathrm{N}$ and longitude $3^{0} 35^{\prime}$ and $4^{0} 42^{\prime} \mathrm{E}$. The park is one of the most popular tourist attractions in Oyo. Within the park facility, there are 17 hotels ranging from 5 star to guesthouse facilities that are 
listed on booking.com. Popular among these are Pretoria guesthouse, Whitefield Hotels and Ragaray Executive Suites and these same facilities offer restaurant services for guests. It is a unique park with a variety of historical and cultural features which is also rich in biodiversity and can boast of an array of exotic flora and diverse wildlife species which serves as the main attractions in the facility. The park is comprised of two previous native administrative forest reserves notably; the Upper Ogun and Oyo-lle Forest Reserves. The facility was named after OyoIle, the old capital city of Oyo Empire. It was initially recognized as two administrative forest reserves, the Upper Ogun in 1936 and Oyo-lle in 1941. The forest reserves were then converted to game reserves in 1952 and later considered as one and elevated to the status of a national park in 1991 (Oyeleye et al., 2018).

Its current location has given it the added advantage of positioning it within the abundant land supply as well as a diversity of wildlife in addition to possessing a barrage of rich cultural and historical settings (Figure 1 shows location of the park facility in Nigeria). Attractions within the park will usually include the following: At the northern portion of the park, a visitor can find various attractions of historic and archaeological value like; the relics of the old city walls of Oyo Ile, the great Agbaku cave which has evidence of Stone Age features, the "Kosomonu" hill, the old Akesan Market, Alaafin's palaces and crucibles of pottery used centuries ago. It also serves as a safe haven for bird watchers (avitourism) as it boasts of over 30 bird species. Visitors are treated to the viewing of a variety of wildlife species at the southern half of the park notably the Nile crocodile, rock pythons, lions, antelopes and buffaloes. Visitors also engage in sports fishing and lake cruising on Ikere Gorge Lake. Within the precincts of the park is also the wildlife museum at Akoto base camp whilst mountaineering opportunities also abound in its central portions (Jumia Travels, 2019). Table 1 shows visitor arrivals to the park from 2013 through 2017, that of 2018 was not yet available at the time of writing this article.

Table 1: Visitor Arrivals to the Park from 2013 to 2017

\begin{tabular}{|c|c|c|c|}
\hline Year & Domestic Arrivals & Foreign Arrivals & Total \\
\hline 2013 & 1685 & 2 & 1687 \\
\hline 2014 & 3617 & 8 & 3625 \\
\hline 2015 & 3785 & 0 & 1940 \\
\hline 2016 & 1938 & 2 & 915 \\
\hline 2017 & 915 & 0 & \\
\hline
\end{tabular}

Source: Old Oyo National Park Administration (2017) 


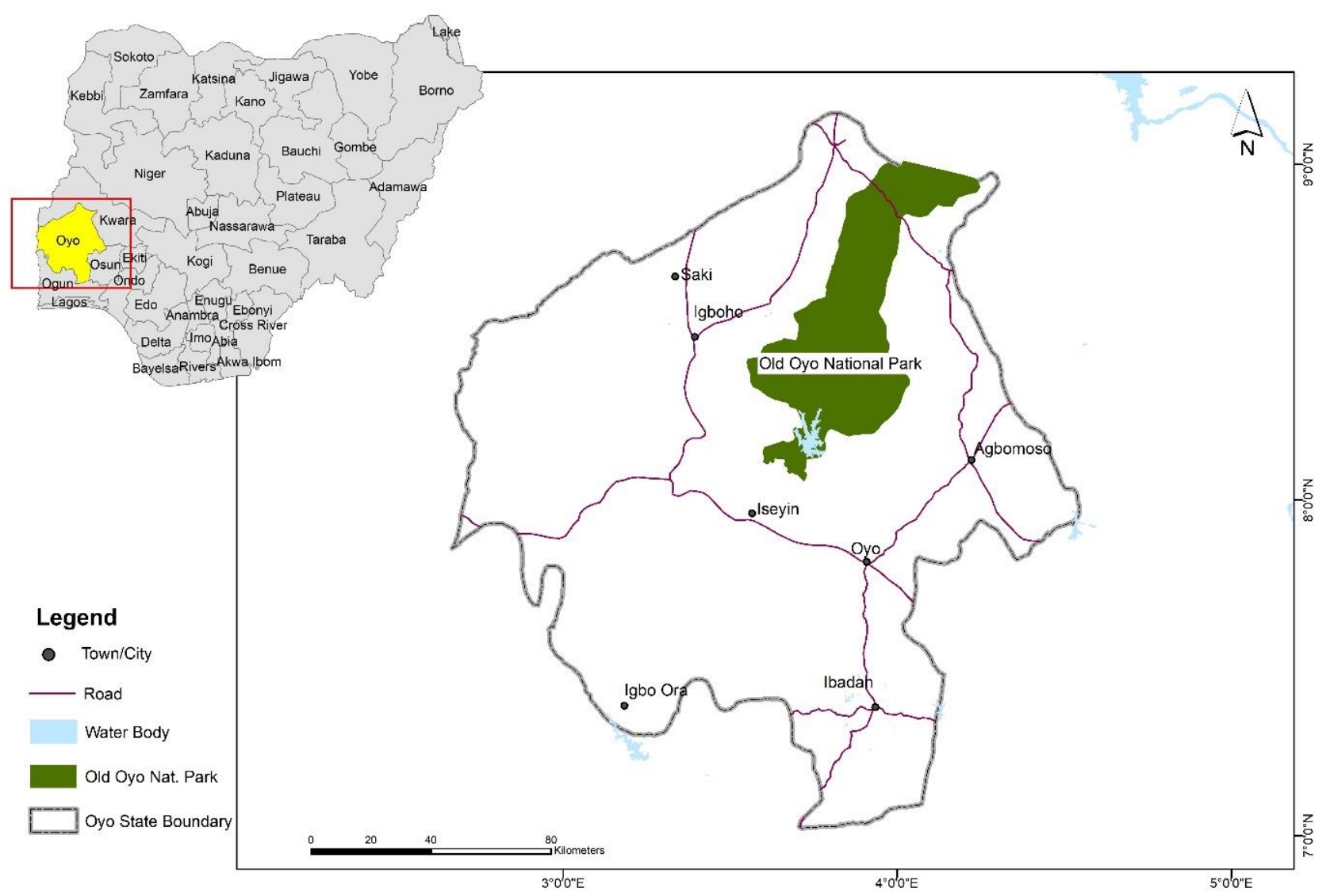

Figure 1: Map showing location of Old Oyo National Park in Nigeria

Source: Harmattan Geo-Spatial Productions (2019)

\section{Research Instrumentation and Data Collection}

The data collection instrument for this study was a structured, self-administered questionnaire designed in English, the official language of Nigeria. In a bid to ensure that the survey questions in this study were valid and reliable, the authors looked at the extent to which a construct (elements of information sought by researchers) was adequately captured, very often referred to as a specification error. This is usually a high-level error, whereas the measurement error is the extent to which a measure (for example a question posed to the respondent) accurately captures the construct. To minimise the validity and measurement/observation errors envisaged in this study, the following stages of evaluation were considered: we engaged the service of 'expert reviews' as the first step to validate the questionnaire (Groves et al., 2009). Expert reviews are where both questionnaire design experts and subject matter experts from academia were contacted to evaluate the content, cognitive, and usability standards of a questionnaire. This was to ensure that any problems the questions and scales had in relation to its scope were highlighted and sorted out. Similarly, the way the questions may be understood or perceived by respondents (whether the questions are clear and easy for participants to understand and answer) is an important step to entrenching validity and reliability (DeMaio \& Landreth, 2004). In this wise, cognitive 
interviewing was also used which is a process whereby participants respond to draft survey questions, and were asked to reveal their thought processes at the same time (Farrall et al., 2012). The premise is that knowing these thought processes and cognitive understanding oftentimes help the researcher(s) to evaluate the quality of the instrument (questionnaire) and the kinds of responses expected to be sourced. A pretest of the instrument was also done in Yankari National Park (also in Nigeria) to 35 visitors mainly to ensure that the kind of responses needed to address our objectives were attained in this study. Regarding the structure of the instrument, the questionnaire was sub-divided into two sections. The first section identified the demographic information from respondents such as gender, age, religion, marital status and occupation while the second section aimed at eliciting data on visitor preferences employing the use of a Likert scale and choice cards. A total of 120 copies of a questionnaire were distributed to visitors met during the three-week period in which the study was undertaken basically from August 1 to 21, 2018. It has been established in research methodology that sample sizes of

\section{Results \\ Socio-demographic characteristics of visitors in Old Oyo National Park}

The results as displayed in Table 2 reveals the demographic profile of the visitors surveyed in Old Oyo National Park where more than half (53.3\%) were male. Majority $(71.7 \%$ ) were single (never married) with about $26.7 \%$ indicating married. A significant percentage of the visitors $(60 \%)$ were between the ages of 21-30years and close to $75.8 \%$ were tertiary education level graduands. Again, a between 30 and 500 at 5\% confidence level are generally significant for researchers to proceed to do analysis (Delice, 2010).

In addition to this, there is also the fact that, the central limit theorem likewise states that the sampling distribution of sample means approach a normal distribution as the sample size gets larger and that no matter the shape of the population distribution, this fact holds accurately true for sample sizes over 30 (Statistics How To, 2020).

The main "setback" as to why some visitors could not be contacted was due to their inability to make time to respond to the questionnaire, citing reasons they came to have fun and so responding to the questionnaire meant the researchers were taking away the quality amusement time they came to spend. The questionnaires were thus administered to visitors in the park who expressed willingness to respond and indeed did fill and return their responses during the data collection period. The data collected were analyzed using descriptive statistics and Conditional Logit specification for inferential statistics.

substantial number of respondents (65\%) who participated in the study were Christian with the rest $(35 \%)$ being Muslim. Furthermore, close to $52.5 \%$ of the visitors were students, $15 \%$ civil servants while $25.8 \%$ indicated they were selfemployed. The study again showed that (19.2\%) of the visitors to the facility earned between N5500 to N50000 with about $10.8 \%$ earning a salary ranging from \#51,000-96,000 monthly. Majority of visitors $(48.3 \%)$ resided within Oyo State while $11.7 \%$ came from Osun State. 
Table 2: Socio-economic Characteristics of Visitors to Old Oyo National Park

\begin{tabular}{|c|c|c|}
\hline Demographic information & Frequency (n) & Percentages \% \\
\hline \multicolumn{3}{|l|}{ Gender } \\
\hline Female & 56 & 46.7 \\
\hline Male & 64 & 53.3 \\
\hline \multicolumn{3}{|l|}{ Age group } \\
\hline $21-30$ & 72 & 60.0 \\
\hline $31-40$ & 13 & 10.8 \\
\hline $41-50$ & 2 & 1.7 \\
\hline Above 50 & 2 & 1.7 \\
\hline \multicolumn{3}{|l|}{ Level of education } \\
\hline Primary & 4 & 3.3 \\
\hline Secondary & 25 & 20.8 \\
\hline Tertiary & 91 & 75.8 \\
\hline \multicolumn{3}{|l|}{ Marital status } \\
\hline Single (never married) & 86 & 71.7 \\
\hline Married & 32 & 26.7 \\
\hline Widowed & 1 & 0.8 \\
\hline Divorced & 1 & 0.8 \\
\hline \multicolumn{3}{|l|}{ Occupation } \\
\hline Civil servant & 18 & 15.0 \\
\hline Self employed & 31 & 25.8 \\
\hline Trading & 8 & 6.7 \\
\hline Students & 63 & 52.5 \\
\hline \multicolumn{3}{|l|}{ Annual income (\#) } \\
\hline $5500-50000$ & 23 & 19.2 \\
\hline $51000-96000$ & 13 & 10.8 \\
\hline 97000-142000 & 7 & 5.8 \\
\hline 143000-188000 & 2 & 1.7 \\
\hline $189000-235000$ & 1 & 0.8 \\
\hline $236000-281000$ & 3 & 2.5 \\
\hline $282000-327000$ & 1 & 0.8 \\
\hline Above 330000 & 4 & 3.3 \\
\hline \multicolumn{3}{|l|}{ State of residence } \\
\hline Abuja & 1 & 0.8 \\
\hline AkwaIbom & 12 & 10.0 \\
\hline Anambra & 1 & 0.8 \\
\hline Benue & 1 & 0.8 \\
\hline Edo & 2 & 1.7 \\
\hline Ekiti & 2 & 1.7 \\
\hline Kogi & 1 & 0.8 \\
\hline Kwara & 2 & 1.7 \\
\hline Lagos & 10 & 8.3 \\
\hline Niger & 3 & 2.5 \\
\hline Ogun & 4 & 3.3 \\
\hline Ondo & 9 & 7.5 \\
\hline Osun & 14 & 11.7 \\
\hline Oyo & 58 & 48.3 \\
\hline
\end{tabular}

Source: Field Survey, 2018 
Pattern of visitation to the park by guests is presented in Table 3 and herein it came to the fore that $77.5 \%$ were first time visitors to the park, while close to $78.3 \%$ came there frequently. Close to $10.2 \%$ of respondents came to the park weekly and these comprised mainly freelance tour guides who frequently brought domestic visitors to access the park on a regular basis as part of the tenets of their job. Other frequent visitors to the park included coach/taxi drivers who brought local guests and also used the opportunity to familiarize themselves with the facility. Also included in this frequent visitation category were suppliers to hotels within the park as well as guests who took advantage of the facilities in the park especially in accessing services of restaurants and bars on a daily basis accounted for only $3.3 \%$ of arrivals. Most of the respondents $(37.5 \%)$ heard about the park from friends while a fair bit $(18.3 \%)$ indicated they were very satisfied with their experience at the facility with majority $(55.8 \%)$ saying they were satisfied.

Table 3: Patterns of Visit, Source of Information and Visitor Satisfaction in the Park

\begin{tabular}{lll}
\hline Variables & Frequency & Percentage (\%) \\
\hline First time of visit & 27 & 22.5 \\
No & 93 & 77.5 \\
Yes & & \\
How often do you visit the park & 94 & 78.3 \\
Frequent & 5 & 4.1 \\
Monthly & 5 & 4.1 \\
Occasionally & 4 & 3.3 \\
Rarely & 12 & 10.2 \\
Weekly & & \\
How did you hear about this park & 45 & 37.5 \\
Friends/family & 6 & 5.0 \\
Advertisement & 25 & 20.8 \\
through internet & 3 & 2.5 \\
Flyers and brochure & 41 & 34.2 \\
Others & & \\
How often do you visit tourist sites & 4 & 3.3 \\
Daily & 6 & 5.0 \\
Weekly & 11 & 9.2 \\
Monthly & 62 & 51.7 \\
Occasionally & 37 & 30.8 \\
Rarely & & \\
Overall visit experience & 22 & 18.3 \\
very satisfied & 67 & 55.8 \\
Satisfied & 16 & 13.4 \\
Undecided & 15 & 12.5 \\
Dissatisfied & &
\end{tabular}

Source: Field Survey, 2018

Results in Table 4 shows findings on factors that determined respondents' preference for tourism related activities in the park. The availability of a variety of recreational facilities attracted the highest mean $(4.30 \%)$ while the existence of 5-star accommodation facilities within the park premises attracted a lower mean rating of $(3.61 \%)$. 
Table 4: Respondents' Preferences

\begin{tabular}{lcccccc} 
VARIABLE & $\mathrm{CNI} \%$ & $\mathrm{NI} \%$ & $\mathrm{NEU} \%$ & $\mathrm{MI} \%$ & $\mathrm{EI} \%$ & mean\% \\
\hline Site's attractiveness & 3.3 & 0.8 & 16.7 & 37.5 & 41.7 & 4.13 \\
Ease of access of the park & 0.8 & 21.7 & 33.3 & 44.2 & 0 & 4.21 \\
Signage and educational guides for tourists & 0 & 2.5 & 20 & 39.2 & 38.3 & 4.13 \\
Appropriate courtesies from staff & 0.8 & 2.5 & 19 & 35 & 42.5 & 4.16 \\
Affordable entry fee & 0.8 & 2.5 & 22 & 35 & 47.5 & 4.09 \\
Variety of recreational facilities & 0 & 0 & 17 & 35 & 47.5 & 4.30 \\
Availability of 5-star accommodation & 7.5 & 3.3 & 31.7 & 35.8 & 21.7 & 3.61 \\
Excellent transport services & 0 & 1.7 & 23.3 & 37.5 & 37.5 & 4.11 \\
\hline
\end{tabular}

Source: Field Survey, 2018

\section{Legend:}

$\mathrm{CNI}=$ Completely Not Important

$\mathrm{NI}=$ Not Important

NEU $=$ Neutral

MI= Moderately Important

$\mathrm{EI}=$ Extremely Important

\section{Preferences for Old Oyo National Park's Features Employing Logit Model Estimates}

An estimation of a conditional logit model was done on the data and results are presented in Table 5. The results show that the cost of entrance fees, availability of chalet accommodation, student-size rooms, wildlife viewing and touring the old city wall of Oyo Ile were the significant predictors of the likelihood of choosing Old Oyo National Park as a tourism destination. From the findings, all the significant variables were positive with the exception of entrance fee which showed negative thus confirming a basic economic theory which postulates that individuals in any market have negative preference for price hikes (this was even after the results revealed that about $76 \%$ of guests to the park had completed tertiary education and were gainfully employed). This is in harmony with a priori expectation; entrance fee was negatively significant at 5\% level of significance implying that the more costly access to the park became in terms of entrance fee, the less likely visitors were willing to choose the park for purposes of tourism and recreation. Within the accommodation attributes, chalet and student-sized rooms showed positively strong signals in predicting the likelihood of choosing the park by respondents. This implied that, in terms of accommodation preferences, chalet accommodation and availability of student-sized rooms served as positive inducement to visitors choosing the park for overnight recreation. In terms of recreation, only wildlife viewing showed a positive prediction regarding choice of the park by respondents for recreation. Among the historical features, the Old City Wall of Oyo Ile did portray a positive likelihood of the park being chosen by the respondents as a tourist destination. 
Table 5: Conditional Logit Model Estimates of Preferences for Features of Old Oyo National Park

\begin{tabular}{llllll}
\hline & Estimate & Std. Error & z-value & $\operatorname{Pr}(>|z|)$ & \\
\hline Entrance Fee & -4.28088 & 1.76249 & -2.4289 & 0.015146 & $* *$ \\
Chalet accommodation & 0.35463 & 0.2038 & 1.7401 & 0.081838 & $*$ \\
Student Sized Rooms & 0.56567 & 0.26779 & 2.1123 & 0.034658 & $* *$ \\
Swimming & 0.61501 & 0.406 & 1.5148 & 0.129824 & \\
Wildlife Viewing & 0.7926 & 0.28848 & 2.7475 & 0.006005 & $* * *$ \\
Public Transport (Taxi) & -0.19626 & 0.24184 & -0.8115 & 0.417051 & \\
Old City Wall of Oyo Ile & 1.5112 & 0.64619 & 2.3386 & 0.019354 & $* *$ \\
The Great Agbaku Cave & 0.49666 & 0.37469 & 1.3255 & 0.184997 & \\
\hline
\end{tabular}

Source: Field Survey, 2018

Significance codes:

$1 \% * * *$

$5 \% * *$

$10 \% *$

\section{Discussion}

The findings contained in this study portrayed that majority of the respondents were male in conformity with similar findings revealed by Cohen et al. (2007) who stated that more males were seen in parks and recreation facilities and often outnumbered their female counterparts in all recreation areas. Again, majority of the "revelers" were between the age of 21-30 years which also lends credence to why most of the respondents were never married probably because they were still schooling (students). The respondents being in their prime ages suggest the economically viable group ready to scout for and expend money on leisure and recreation as opined by Ogunbodede (2012). A high percentage of the visitors to this park have had some education up to tertiary level and earned well above $\$ 51,000$ and this further validates a research finding carried out by Sangsun (2010) who indicated visitor responses to physical conditions were highly influenced by education levels and income. An earlier research by Ridgway et al. (2005) which sought to suggest that majority of visitor groups lived in the same city as the recreational site they visited seems to support the current findings of the study where majority of the respondents who lived within the state that housed

the national park were actually the leading patrons of the facility and in this case residents of Oyo State very often trooped in.

Majority of the respondents were also first-time visitors to the park implying that the park administration was engaging in effective publicity strategies that attracted "first timers" as supported by Ma et al. (2018) who brought to the fore the fact that majority of respondents to Dinghushan National Nature Reserve in the Guangdong Province of China were actually first-time visitors. A greater proportion of the respondents indicated friends and relatives as their source of information search about the park. Close to $74.1 \%$ (that is, 18.3 very satisfied and 55.8, satisfied) expressed satisfaction with their overall visitor experience to the park, consistent with the assertion by Truong and King (2009) who noted that visitor satisfaction is an important concept in marketing and acts as a key influence over future purchase, market share and word of mouth publicity to potential visitors.

The study again brought to the fore the fact that visitor preferences for tourism in Old Oyo National Park were influenced by a variety of recreational facilities inherent in the facility. Attractiveness of park, its old age, availability of trails and biotopes, 
appropriate signage in addition to the presence of knowledgeable and well-informed guides. These site attributes both environmental and human were on 'display' upon arrival of the guests and this had an impact on the overall image of the facility and the quality of the service encounter experienced which is thought to have a significant influence on customer fulfillment in the tourism and hospitality industry as posited by Ryu and Jang (2008).

The hospitality bid of staff working in the park which heralded appropriate courtesies accorded visitors was also identified as key in determining visitor's preference for the park. The staff were thought to have related very well with visitors thereby improving the quality of their experience. Friendliness of park employees to guests of diverse backgrounds was revealed as relevant in making their stay experience memorable in the park, this is in consonance with the findings of Genest and Legg (2003) who noted that a premier destination is the one that provides a quality tourist product and experience. It again further supports the assertion of Wright et al. (2001) that tourism and hospitality is a labour-intensive industry which frequently involves interaction between people.

Furthermore, reliable transportation services to the park, ease of accessibility within the park, good accommodation facilities and affordable entrance fees were also revealed as qualities influencing visitor preferences for tourism at the park. This seems to be in tandem with a study by Eraqi (2006) who revealed that tourists' satisfaction with regard to quality depended upon a number of criteria, such as the general evaluation of tourism and hospitality services, the extent to which tourists are satisfied

\section{Conclusion}

This study revealed that site features and hospitality services influence visitors' preferences in Old Oyo National Park with emphasis placed on entrance fee, availability of chalet accommodation and student-sized rooms. Other itinerary of interest when visiting the park included opportunities to view wildlife in their natural habitat from the convenience and comfort of their accommodation with the hospitality outlet's services. Others include, customers view of the tourism services' prices, the level of professionalism with which services are rendered at accommodation facilities, internal transport quality, the extent to which tourism services prices are pegged at suitable levels and tourists' desire to repeat his/her visit.

The estimation of conditional logit model has revealed entrance fee, availability of chalet accommodation and that of student-sized rooms, wildlife viewing opportunities and touring the old city wall of Oyo Ile were the significant predictors of the likelihood of choice of Old Oyo National Park as a tourism destination. These attributes would "stimulate" visitors" satisfaction with the attraction and thus confirms similar findings of Truong and King (2009) who identified the factors that affected the satisfaction of Chinese tourists who visited Vietnam and found these to include varied and beautiful scenery, a multiplicity of activities to be engaged in by visitors, a variety of quality restaurants, quality and standard accommodation, safety, friendliness and hospitality of local people, availability of shopping facilities including attractive nightlife and entertainment. Emphasis was also placed on; the level of professionalism with which immigration staff went about their duties including the ease of customs clearance which guests noted as commendable. Political stability of the destination, social and educational value of the tour, variety of cultural events and festival/festive occasions including availability of souvenirs to be purchased as these also attracted the foreign guests in particular.

facilities in the park. These have been noted to entice most of the guests who came visiting the park. The study also noted that touring the relics of the old city wall of Oyo Ile was a great piece of attraction. Guests took interest in the history of these relics and so left the park premises more appreciative of the culture of their immediate neighbourhoods and environs. Staff of the park were noted to be very hospitable (courteous) in all 
their engagements with visitors in the park. Hospitality of staff in itself is a noted (virtue) attraction in destination areas which adds to the satisfaction experience of the guest. The study again brought to the fore the fact that the 'lead' patrons to the park were natives of the Oyo State followed by other nearby states such as Osun and Lagos, hence hinting on the proximity factor which tended to lure many guests to visit many tourist facilities near them.

\section{Recommendations}

The study made the following recommendations:

The management of Old Oyo National Park needs to continually develop the attractions stock in the park to bring about a greater variety. Variety will entice visitors to continually patronize the facility and it is hereby recommended that visitor satisfaction surveys should be conducted so that the guests themselves can periodically update

\section{References}

Census and Economic Information Centre [CEIC] Global Database (2019). Nigeria visitor arrivals. Retrieved $9^{\text {th }}$ January, 2020 from website https://www. ceic data.com/en/ indicator/nigeria/visitor-arrivals.

Chandler, J. A., \& Costello, C. A. (2002). A profile of visitors at heritage tourism destinations in east Tennessee according to Plog's lifestyle and activity level preferences model. Journal of Travel Research, 41: 161-166.

Cohen, A., McKenzie, T., Sehgal, A., Williamson, S., Golinelli, D., \& Lurie, N. (2007). Contributions of public parks to physical activity. America Journal of Public Health, 97(3): 509-514.

Delice, A. (2010). The sampling issues in quantitative research. Retrieved $4^{\text {th }}$ September, 2020 from website: https://files.eric.ed.gov/fulltext/EJ919871. pdf management on what to do to make visitors better satisfied. Ways to attain this include, periodically engaging the visitors themselves through one-onone interactive interview sessions (by park staff) to identify activities that are of interest to guests but non-existent in the park and which later can be developed and included in the park's array of activities to engage the visitors all day long. Additionally, customer comment cards left in the guestrooms and at the park reception or even at eatery joints in the park can be used to facilitate this. There is need also for in-service training of staff to be led by industry players so that they are continually abreast with service provision 'tactics' in the industry and to equally share experiences on improving their services to render to the guests a unique and memorable experience. This will enable the park benefit from word-of-mouth publicity emanating from these same visitors who had the opportunity to experience their services.

DeMaio, T., and Landreth, L. (2004). Do different cognitive interview techniques produce different results? In S. Presser, J. Rothgeb , M. Couper, J. Lessler E. Martin, J. Martin, and E. Singer (eds.), Methods for Testing and Evaluating Survey Questionnaires, pp 89-108. New York: Wiley.

Dolnicar, S., Crouch, G. I., \& Long, P. (2008). Environment-friendly tourists: What do we really know about them? Journal of Sustainable Tourism, 16(2): 197-210.

Eraqi, M. I. (2006). Tourism services quality (TourServQual) in Egypt: The viewpoints of external and internal customers. Benchmarking: An International Journal, 13(4): 469-492.

Farrall, S., Priede, C., Ruuskanen, E., Jokinen, A., Galev, T., Arcai, M. \& Maffei, S. (2012). Using cognitive interviews to refine translated survey questions: An example from a cross-national crime survey. International Journal of Social Research Methodology, 15: 467-483. 
Genest, J., \& Legg, D. (2003). The premier-ranked destinations workbook 2001. Retrieved $30^{\text {th }}$ July 2019 from website:www.ttra.com/ publications/uploads/o32.pdf

Githiri, M. N. (2016). Influence of physical environment on customer satisfaction and return intention in Kenyan Rated Restaurants. Asian Journal of Social Science Studies, 2(1), 2017.

Groves, R.M., Fowler, J.J.J., Couper, M.P., Lepkowski, J.M., Singer, E. \& Tourangeau, R. (2009). Survey methodology (2nd ed.). Wiley.

Hardy, A., \& Pearson, L. J. (2016). Determining sustainable tourism in regions. Sustainability. Retrieved $21^{\text {st }}$ June 2019 from website.

https://pdfs.semanticscholar.org/a45d/7cb 73d3588f840c4b5851acb33fcc9acbf0e.pdf

Hearne, R. R., \& Salinas, Z. M. (2002). The use of choice experiments in the analysis of tourist preferences for ecotourism development in Costa Rica. Journal of Environmental Management, 65: 153-163.

Honey, M., \& Krantz, D. (2007). Global trends in coastal tourism. Center for Ecotourism and Sustainable Development.

International Finance Corporation [IFC] (2004) Eco-lodges: Exploring opportunities for Sustainable Business. International Finance Corporation.

Jumia Travels (2019). Old Oyo National Park. Retrieved $18^{\text {th }}$ July 2019 from website: https://travel.jumia.com/engb/destinations/old-oyo-national-park10003285

Juutinen, A. Mitani, Y., Mantymaa, E., Shoji, Y., Siikamaki, P., \& Svento, R. (2011). Combining ecological and recreational aspects in national park management: A choice experiment application. Ecological Economics, 70(6): 1231-1239.

Kajala, L. Almik, A. Dahl, R. Diksaite, L. Erkkonen, J. Fredman, P. Jensen, F.S. Karoles, K. Sievänen, T., \& Skov-Petersen, H. (2007). Visitor monitoring in nature areas: A manual based on experiences from the
Nordic and Baltic Countries. Swedish Environmental Protection Agency.

Kariru A. N, \& Aloo, C. (2014). Customers' perceptions of service quality in hotels in western tourism circuit, Kenya. Journal of hospitality, tourism and culture, 2(1): 1-12.

Ma, A., Chow, A., Cheung, L., Lee, K., \& Liu, S. (2018). Impacts of tourists' sociodemographic characteristics on the travel motivation and satisfaction: The case of protected areas in South China. Sustainability, 10(10): 33-88.

Magnini, V.P., \& Parker, E.E. (2009). The psychological effect of music: Implications for hotel firms. Journal of Vacation Marketing, 15(1): 53-62.

Mihajlović, I. \& Krželj-Čolović, Z. (2014). The impact of globalisation on the development of tourism within social and economic changes. European Scientific Journal. August Special Edition, 2014.

Ogunberu A. F. (2011). Socio-economic impact of Tourism Development in Nigeria; Case study of tourist attractions along the coastline of Lagos. Retrieved $11^{\text {th }}$ August 2019 from website https://www.theseus.fi/handle/10024/31193.

Ogunbodede E. F. (2012). Patronage pattern of tourists to Idanre Hills and its implications for tourism development in Nigeria. Journal of Environmental Research and Development. 6(3): 908-915.

Oyeleye, D. O., Halidu, S. K., Abdulkadir, A. T. Olaoye, O., Emmanuel, J. B. \& Oyetunji, K. S. (2018). Roles of local leaders on wildlife conservation effort in Old Oyo National Park, Nigeria. Journal of Research in Forestry, Wildlife \& Environment, 10(1): 107-117.

Oh, C. O., Draper, J., \& Dixon, A.W. (2010). Comparing resident and tourist preferences for public beaches and related amenities. Ocean Coast Management, 53: 245-251.

Prato, T., \& Fagre, D. (2005). National parks and protected areas: Approaches for balancing 
social, economic and ecological values. Blackwell Publishing.

Ridgway S.C., Livingston M., \& Smith S.E. (2005). Visitor behavior in zoo exhibits with underwater viewing: A publication of Visitors Studies Association, 8(3): 1-10.

Ryu, K., \& Jang, S. (2008). DINESCAPE: A scale for customers' perception of dining environment. Journal of Food Service Business Research, 11(1): 2-22.

Sangsun, P. (2010). Environmental impact of tourism in KhaoYai National Park, Thailand. Graduate Studies of Texas A\&M University.

Shiang, M. M., Gin, S. L., \& Shih, H. Y. (2011). The relationship between cruise image, perceived value, satisfaction and post-purchase behavioural intention of Taiwanese tourists. Africa Journal of Business Management, 5(1): 19-29.

Statistics How To (2020). Statistics for the rest of us. Retrieved $3^{\text {rd }}$ November 2020 from website: https://www.statisticshowto.com/probability -and-statistics/normal-distributions/centrallimit-theorem-definition-examples/

Truong, T. H. \& King, B. (2009). An evaluation of satisfaction among Chinese tourists in Vietnam. International Journal of Tourism Research, 11: 521-535.

Tuzunkan, D., \& Albayrac, A. (2016). The importance of restaurant physical environment for Turkish customers. Journal of Tourism Research and Hospitality. Retrieved $24^{\text {th }}$ February 2019 from website https://www.scitechnol.com/peerreview/the-importance-of-restaurantphysical-environ ment-for-turkishcustomers-3yJe.php?

Wright, P., Dunford, B., \& Snell, A. (2001). Human resources and the resource-based view of the firm. Journal of Management, 27: 701-721. 